\title{
Persistence in Temporary Lung Niches: A Survival Strategy of Lung-Resident Memory CD8 ${ }^{+} \mathrm{T}$ Cells
}

\author{
Shiki Takamura
}

\begin{abstract}
Respiratory virus infections, such as those mediated by influenza virus, parainfluenza virus, respiratory syncytial virus (RSV), severe acute respiratory syndrome coronavirus (SARS-CoV), rhinovirus, and adenovirus, are responsible for substantial morbidity and mortality, especially in children and older adults. Furthermore, the potential emergence of highly pathogenic strains of influenza virus poses a significant public health threat. Thus, the development of vaccines capable of eliciting long-lasting protective immunity to those pathogens is a major public health priority. $\mathrm{CD}^{+}$Tissue-resident memory $\mathrm{T}\left(\mathrm{T}_{\mathrm{RM}}\right)$ cells are a newly defined population that resides permanently in the nonlymphoid tissues including the lung. These cells are capable of providing local protection immediately after infection, thereby promoting rapid host recovery. Recent studies have offered new insights into the anatomical niches that harbor lung $\mathrm{CD}^{+} \mathrm{T}_{\mathrm{RM}}$ cells, and also identified the requirement and limitations of $\mathrm{T}_{\mathrm{RM}}$ maintenance. However, it remains controversial whether lung $\mathrm{CD} 8^{+} \mathrm{T}_{\mathrm{RM}}$ cells are continuously replenished by new cells from the circulation or permanently lodged in this site. A better understanding of how lung $\mathrm{CD}^{+} \mathrm{T}_{\mathrm{RM}}$ cells are generated and maintained and the tissue-specific factors that drive local $\mathrm{T}_{\mathrm{RM}}$ formation is required for optimal vaccine development. This review focuses on recent advance in our understanding of $\mathrm{CD}^{+} \mathrm{T}_{\mathrm{RM}}$ cell establishment and maintenance in the lung, and describes how those processes are uniquely regulated in this tissue.
\end{abstract}

Keywords: lung, memory $\mathrm{CD}^{+} \mathrm{T}$ cells, tissue-resident memory

\section{Introduction}

$\mathbf{M}$ EMORY T CELlS HAVE been divided into two distinct subsets based on their distinct migratory properties (107). Central memory $\mathrm{T}\left(\mathrm{T}_{\mathrm{CM}}\right)$ cells express lymph nodehoming receptors L-selectin (CD62L) and CC-chemokine receptor 7 (CCR7), and preferentially circulate between lymph nodes and blood. Effector memory $\mathrm{T}\left(\mathrm{T}_{\mathrm{EM}}\right)$ cells lack the expressions of these receptors and circulate between the blood and nonlymphoid barrier tissues such as the skin, lung, intestines, and female reproductive tract. Upon secondary infection, $\mathrm{T}_{\mathrm{EM}}$ cells exhibit immediate effector functions at the site of infection, while $\mathrm{T}_{\mathrm{CM}}$ cells undergo extensive expansion in the draining lymph nodes before migrating to the site of infection and eliminating virus-infected cells (106). It has recently emerged that memory $\mathrm{T}$ cells in the nonlymphoid tissues, which had previously been classified as a circulating $\mathrm{T}_{\mathrm{EM}}$ population, include a noncirculating cell population that resides permanently within the peripheral tissues. These cells have been termed tissue-resident memory $\mathrm{T}\left(\mathrm{T}_{\mathrm{RM}}\right)$ cells (34) and comprise the majority of memory $\mathrm{T}$ cells in the nonlymphoid tissues that confer immediate protection against peripheral infection (119). Low levels of $\mathrm{T}_{\mathrm{EM}}$ cells also transit the peripheral tissues and contribute to local protection (83). More recent studies have revealed that $\mathrm{T}_{\mathrm{RM}}$ cells are present in wide variety of lymphoid and nonlymphoid tissues, including brain, salivary glands, thymus, spleen, lymph nodes, liver, kidneys, pancreas, heart, and dorsal root ganglia (96). The generation and maintenance of $\mathrm{T}_{\mathrm{RM}}$ cells in each of these tissues differ significantly, indicating a major role for tissue-specific instruction (53). Therefore, there is a need to identify the unique signals underlying each tissue microenvironment and the molecular mechanisms that instruct $\mathrm{T}_{\mathrm{RM}}$ formation.

During primary respiratory virus infections, antigenspecific $\mathrm{CD} 8^{+} \mathrm{T}$ cells are crucial to the elimination of virusinfected cells and in the case of influenza viruses, cross reactive $\mathrm{CD}^{+} \mathrm{T}$ cell-mediated immunity can provide

Department of Immunology, Kindai University, Faculty of Medicine, Osaka, Japan.

(C) Shiki Takamura, 2017; Published by Mary Ann Liebert, Inc. This Open Access article is distributed under the terms of the Creative Commons Attribution Noncommercial License (http://creativecommons.org/licenses/by-nc/4.0/) which permits any noncommercial use, distribution, and reproduction in any medium, provided the original author(s) and the source are credited. 
protection against different viral strains (heterosubtypic immunity) (21). Thus, understanding the mechanisms by which $\mathrm{CD}^{+} \mathrm{T}_{\mathrm{RM}}$ cells are established in the lung has important implications for vaccine development. Following resolution of respiratory virus infections, $\mathrm{CD}^{+} \mathrm{T}_{\mathrm{RM}}$ cells persist in at least two distinct compartments of the lung: the lung interstitium/parenchyma and the lung airways (44). $\mathrm{CD}^{+} \mathrm{T}_{\mathrm{RM}}$ cells in the lung interstitium/parenchyma are mainly found as confluent peribronchiolar cell infiltrates in the interstitium and alveolar spaces (123). Note that the term "lung parenchyma" indicates a part of lung involved in gas exchange, such as the alveoli, alveolar ducts, and respiratory bronchioles, but does not include the lung interstitium. In contrast, $\mathrm{CD}^{+} \mathrm{T}_{\mathrm{RM}}$ cells in the lung airways are localized primarily in the epithelial layers of the upper respiratory tract and can be easily isolated by bronchoalveolar lavage (BAL) $(25,47,48)$. Both $\mathrm{T}_{\mathrm{RM}}$ populations confer rapid protection against secondary infection $(37,91,135)$, and the number of antigen-specific $\mathrm{CD}^{+} \mathrm{T}_{\mathrm{RM}}$ cells in those tissues correlates with the efficacy of protection. Importantly, however, the molecular and cellular mechanisms underlying their recruitment, differentiation, maintenance, and recall differ significantly (44). Thus, the precise discrimination of those populations is necessary to comprehensively understand $\mathrm{CD}^{+} \mathrm{T}$ cell-mediated antiviral immunity in the lung.

This review will focus primarily on influenza and parainfluenza virus infections and discuss recent insights into the course of $\mathrm{CD}^{+} \mathrm{T}_{\mathrm{RM}}$ cell establishment in the lung interstitium/ parenchyma and airways, from initial priming, to tissue migration, local differentiation, and maintenance.

\section{Priming of $\mathrm{CD}^{+} \mathrm{T}$ Cells Following Respiratory Virus Infection}

$\mathrm{CD}^{+} \mathrm{T}$ cell priming following a respiratory virus infection occurs in the lung-draining mediastinal lymph nodes (MLN) after lung-resident antigen-presenting cells (APCs) have transported viral antigens to that site. Lymph noderesident $\mathrm{CD} 8 \alpha^{+}$conventional dendritic cells (DCs) that acquire antigens from migrant respiratory DCs were initially thought to be pivotal in the initiation of antiviral $\mathrm{CD}^{+} \mathrm{T}$ cell responses (10). It has recently become apparent, however, that two subsets of respiratory DCs transport viral antigens from the lung and prime naive $\mathrm{CD} 8^{+} \mathrm{T}$ cells in the MLN (60). Moreover, those two DC subsets exhibit distinct $\mathrm{T}$ cell stimulatory functions and also regulate the tempo of migration to the MLN upon infection, resulting in the generation of distinct memory $\mathrm{CD}^{+} \mathrm{T}$ cell subsets in both lymphoid and nonlymphoid tissues $(11,35)$. In brief, CD103 respiratory DCs that reside between/below epithelial cells possess the specialized ability to uptake apoptotic cellassociated antigens (e.g., virus-infected cells) and crosspresent them on the MHC class I molecules $(20,43,46)$. Upon infection, migration of antigen-laden $\mathrm{CD} 103^{+}$respiratory DCs to the MLN dominates the early stage of infection (24 days) $(36,60)$. These $\mathrm{CD} 103^{+}$respiratory DCs express high levels of the costimulatory molecule CD24, which has been decorated with high mobility group box 1 (HMGB1), a damage-associated molecular pattern (DAMP) released from dying cells, thereby providing strong stimulatory signals to $\mathrm{CD}^{+} \mathrm{T}$ cells through its ligand, receptor for advanced glycan end-products (RAGE) (61). $\mathrm{CD}^{+} \mathrm{T}$ cells activated by these
$\mathrm{CD} 03^{+}$respiratory DCs proliferate vigorously and become potent effector cells that preferentially home back to the lung to eliminate virally infected cells $(36,52)$. Since entry into the peripheral tissues is necessary for subsequent differentiation into $\mathrm{CD}^{+} \mathrm{T}_{\mathrm{RM}}$ cells, priming with $\mathrm{CD} 103^{+}$respiratory $\mathrm{DCs}$ is potentially the primary factor controlling the development of $\mathrm{T}_{\mathrm{RM}}$ cells. In contrast, $\mathrm{CD} 11 \mathrm{~b}^{\text {hi }}$ respiratory $\mathrm{DCs}$ transport and cross-present viral antigens in the MLN at later time points during the infection $(5-7$ days) $(7,60,94)$. Those include cells that originally reside in the lung interstitium and new emigrants to the lung in response to inflammation (e.g., monocyte-derived DCs) (35). CD1 $1 b^{\text {hi }}$ respiratory DCs uniquely upregulate CD70, the ligand for CD27, in response, in part, to thymic stromal lymphopoietin (TSLP) secreted by virus-infected lung epithelial cells (136), and are thus capable of providing costimulatory signals to $\mathrm{CD}^{+} \mathrm{T}$ cells (7). Several lines of evidence support the notion that $\mathrm{CD} 11 \mathrm{~b}$ hi respiratory DCs contribute less to antiviral $\mathrm{CD}^{+} \mathrm{T}$ cell immunity than $\mathrm{CD} 103^{+}$respiratory DCs because only the selective loss of $\mathrm{CD}_{103^{+}}$respiratory DCs leads to a severe reduction in the antigen-specific $\mathrm{CD}^{+} \mathrm{T}$ cell responses $(36,46,60,100)$. The weaker stimulatory potential of $\mathrm{CD} 11 \mathrm{~b}^{\mathrm{hi}}$ respiratory DCs presumably explains their characteristics: preferential generation of the memory $\mathrm{CD}^{+} \mathrm{T}$ cell population that persists in the secondary lymphoid organs, rather than generation of fully differentiated effector $\mathrm{CD}^{+} \mathrm{T}$ cells (61). Thus, the distinct functionality of respiratory DC subsets critically impacts the memory $\mathrm{CD}^{+} \mathrm{T}$ cell heterogeneity.

A study by Mikhak et al. has suggested that lung DCs are capable of imprinting $\mathrm{CD} 4^{+} \mathrm{T}$ cell homing to the lung through selective upregulation of CCR4 (93). However, since lung DCs from naive animals that are expanded by injection of fms-like tyrosine kinase 3 ligand (Flt3L) have been demonstrated in this study, it is unclear which DC populations contributed to the lung imprinting. Considering the migratory property of activated T cells to the lung, it is likely that DCs purified from Flt3L-treated lung tissues largely contain lungresident $\mathrm{CD} 103^{+} \mathrm{DCs}$, but not $\mathrm{CD} 11 \mathrm{~b}^{\text {hi }}$ DCs. It is interesting to speculate whether lung imprinting signals could also affect $\mathrm{CD}^{+} \mathrm{T}$ cells.

\section{Recruitment of $\mathrm{CD8}^{+} \mathrm{T}$ Cells to the Lung}

\section{New definitions provided by intravascular staining}

Intravascular (i.v.) staining of cells in the bloodstream by i.v. injection with specific antibodies before harvesting the cells has revolutionized the analysis of lung $\mathrm{T}_{\mathrm{RM}}(5,6)$. Since the lung is a highly vascularized organ, it became apparent that a majority of $\mathrm{CD}^{+} \mathrm{T}$ cells purified from the lung tissues in earlier studies were contaminants from the blood. In fact, $>95 \%$ of total $\mathrm{CD}^{+} \mathrm{T}$ cells in naive animals and $\sim 50 \%$ of antigen-specific memory $\mathrm{CD}^{+} \mathrm{T}$ cells in mice that had recovered from an influenza virus infection were found to be derived from the lung vasculature $(6,126)$. Note that because the lung airways are segregated from the blood vessels, i.v. staining has essentially no impact on the cells in these tissues. However, a careful reinterpretation of previously published data regarding cells in the lung interstitium/parenchyma analyzed without i.v. staining is required. For instance, it has been reported that antigen-specific $\mathrm{CD}^{+} \mathrm{T}$ cells generated by intraperitoneal infections were efficiently recruited to the interstitium/parenchyma, but not to the lung airways when the 
effector T cell numbers peak (9-11 days) even in the absence of progressive infection or inflammation in the lung (122). Furthermore, parabiosis experiments in which pairs of mice are surgically joined revealed that significant numbers of memory $\mathrm{CD} 8^{+} \mathrm{T}$ cells could also be recruited to the lung as up to half of the cells in this organ were replaced by circulatory $\mathrm{CD}^{+} \mathrm{T}$ cell populations $(63,84)$. By using i.v. staining, those conclusions have been revised. First, although effector $\mathrm{CD} 8^{+}$ $\mathrm{T}$ cells migrate into the interstitium of normal lungs more efficiently than naive $\mathrm{CD}^{+} \mathrm{T}$ cells (33), the extent is much less than that observed in the presence of infection/inflammation in the lung (123). Second, the migration of circulating memory $\mathrm{CD}^{+} \mathrm{T}$ cells to the lung under steady-state conditions is also relatively limited, as the ratio of new immigrants to resident cells never exceeds $20 \%$ (123). On the basis of these new findings, we propose that the migration of effector as well as naive /memory $\mathrm{CD} 8^{+} \mathrm{T}$ cells into the noninflamed lung be termed as "basal recruitment" and be distinguished from "active recruitment": migration of antigen-specific effector $\mathrm{CD} 8^{+} \mathrm{T}$ cells to the lung in response to inflammation in the tissues (Fig. 1). Strict discrimination between basal and active recruitment is important because tissue-derived instructive factors (e.g., antigen and inflammatory stimuli) that dictate $T_{R M}$ differentiation differs significantly depending on how the cells were recruited.

\section{Influence of chemokines on the active and basal recruitment of $C D 8^{+} T$ cells to the lung}

Unlike skin and intestines, where specialized adhesion molecules and chemokine receptors regulate selective migration of $\mathrm{T}$ cells to those tissues (e.g., integrin $\alpha 4 \beta 7$ and

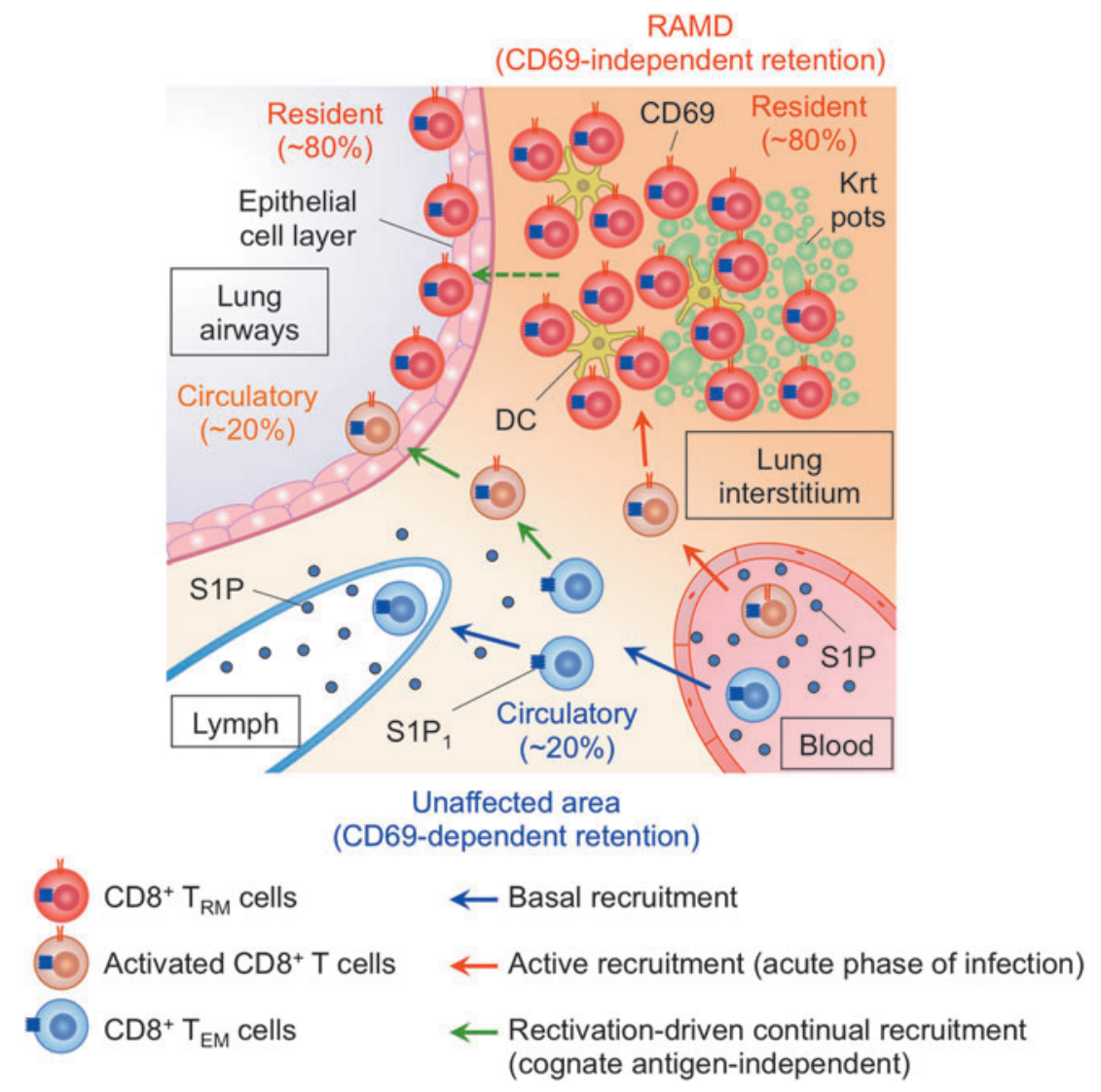

FIG. 1. Compartmentalization of $\mathrm{CD}^{+} \mathrm{T}_{\mathrm{RM}}$ cells and $\mathrm{CD}^{+} \mathrm{T}_{\mathrm{EM}}$ cells in the lung. Memory $\mathrm{CD} 8^{+} \mathrm{T}$ cells in the lung consists of a major $(\sim 80 \%)$ population of $\mathrm{T}_{\mathrm{RM}}$ cells and a minor $(\sim 20 \%)$ population of $\mathrm{T}_{\mathrm{EM}}$ cells. During the acute phase of a respiratory virus infection, effector $\mathrm{CD}^{+} \mathrm{T}$ cells are recruited to the lung (active recruitment) and acquire tissuederived instructions necessary for differentiation into terminal effector cells. $\mathrm{CD}^{+} \mathrm{T}_{\mathrm{RM}}$ precursors are recruited to the site of tissue damage during later stages of the infection and receive instructive signals from several factors (such as local antigen and TGF- $\beta$ ) before differentiating into $\mathrm{T}_{\mathrm{RM}}$ cells. $\mathrm{CD}^{+} \mathrm{T}_{\mathrm{RM}}$ niches (RAMDs) are created as a consequence of tissue remodeling and provide temporal spaces for the maintenance of CD8 ${ }^{+} \mathrm{T}_{\mathrm{RM}}$ cells. CD8 ${ }^{+} \mathrm{T}_{\mathrm{RM}}$ cells in the RAMDs are maintained in a CD69-independent manner due to spatial separation from the lymphatics. Because CD8 ${ }^{+} \mathrm{T}_{\mathrm{RM}}$ cells in the lung airways are short-lived, this population may be maintained by the continual recruitment of cells from the CD8 ${ }^{+} \mathrm{T}_{\mathrm{RM}}$ pool in the lung interstitium/parenchyma. $\mathrm{CD}^{+} \mathrm{T}_{\mathrm{EM}}$ cells are recruited to the uninfected lung interstitium during steady state (basal recruitment). Those cells are segregated from the $\mathrm{CD} 8^{+} \mathrm{T}_{\mathrm{RM}}$ niches and residual antigen-presenting cells in the lung, thereby causing them to exit from this tissue through the lymph in response to S1P-induced chemotactic signal. Some cells are activated by antigen-independent stimulus in the interstitium and transiently express CD69. CD69-mediated inhibition of $\mathrm{S}_{1} \mathrm{P}_{1}$ leads to temporal retention of $\mathrm{CD}^{+} \mathrm{T}_{\mathrm{EM}}$ cells in the interstitium, which potentially enable subsequent recruitment of cells to the lung airways. RAMDs, repair-associated memory depots; S1P, sphingosine 1-phosphate; $\mathrm{T}_{\mathrm{EM}}$, effector memory $\mathrm{T}$; TGF- $\beta$, transforming growth factor- $\beta$; $\mathrm{T}_{\mathrm{RM}}$, tissue-resident memory $\mathrm{T}$. 
CCR9 for the intestines, and cutaneous lymphocyteassociated antigen [CLA], CCR4, and CCR10 for the skin, respectively), molecules that specifically regulate $\mathrm{T}$ cell trafficking to the lung have not yet been reported. Instead, general factors such as lymphocyte function-associated antigen-1 (LFA-1) (125) and inflammatory chemokine receptors CCR5 and CXC chemokine receptor 3 (CXCR3) have been shown to be involved (134).

CCR5 ligands are constitutively expressed in the normal lung and regulate the basal recruitment of $\mathrm{CCR}^{+}$effector $\mathrm{CD}^{+} \mathrm{T}$ cells to the interstitium (33). Upon respiratory virus infection, the expression of CCR5 binding chemokines as well as CXCR3 binding chemokines is upregulated in the lung $(64,134)$, and various cell types are involved in the secretion of these chemokines, including epithelial cells, DCs, macrophages, endothelial cells, and mast cells $(22,99,124)$. CCR5 is also transiently expressed on the surface of antigen-experienced $\mathrm{CD}^{+} \mathrm{T}$ cells in the circulation shortly after respiratory virus infection (peaking at day 2 postinfection), and this upregulation is probably induced by proinflammatory cytokines (64). Since only limited numbers of virally primed antigen-specific $\mathrm{CD} 8^{+} \mathrm{T}$ cells exist at this time point, CCR5-mediated active recruitment of cells to the lung airways is antigen independent (23). This influx (3-5 days) is a part of acute response during respiratory virus infections (44), and antigen-nonspecific memory $\mathrm{CD}^{+} \mathrm{T}$ cells recruited to the lung airways provide "innate" protection (64). Nevertheless, the lack of CCR5 alone has essentially no impact on the active recruitment of expanded antigen-specific effector $\mathrm{CD}^{+} \mathrm{T}$ cells to the lung (5-10 days) $(30,66)$, suggesting the redundancy of signals through various inflammatory chemokine receptors in this process.

In contrast to CCR5, CXCR3 is expressed in a large fraction of antigen-specific effector as well as memory $\mathrm{CD} 8^{+} \mathrm{T}$ cells, and plays a major role in the active recruitment of those cells to the inflamed lung $(30,77,111)$. After entry into the lung, CXCR3 ligands guide effector $\mathrm{CD}^{+} \mathrm{T}$ cells to the sites of infection/inflammation in the lung and accelerate effector maturation (66). Some cells maintain the expression of CXCR3 and are preferentially recruited to the vicinity of virus-infected epithelial cells and airway lumen, while cells that receive signals from IL-12 and IL-15 downregulate CXCR3 and are retained in the peribronchioarterial area where they provide a "second wave" of protection (1). Interestingly, Lim et al. have demonstrated that neutrophils that infiltrated the lung during the early phase of infection (around day 4) leave long-lasting trails of CXCL12 that guide and accelerate the migration of effector $\mathrm{CD}^{+} \mathrm{T}$ cells to the lung airways in a CXCR4-dependent manner (76). Thus, CXCR3 and CXCR4 cooperatively regulate the active recruitment of cells into the inflamed lung. CXCR3 also contributes to the basal recruitment of memory $\mathrm{CD}^{+} \mathrm{T}$ cells to the lung airways in the absence of any infection in the lung (116). This feature may reflect, in part, the superior functionality of $\mathrm{CXCR}^{\text {hi }}{ }^{\text {memory }} \mathrm{CD}^{+} \mathrm{T}$ cells in mounting recall responses against respiratory virus infection (45).

It has also been reported that $\mathrm{CXCR}^{+}$memory $\mathrm{CD}^{+} \mathrm{T}$ cells accumulate in the lung following intranasal, but not intradermal delivery of antigen (72,73). In fact, the expression of CXCL16 is strongly enhanced in response to inflammatory stimuli, thereby accelerating the active re- cruitment of effector T cells into inflamed tissues $(2,38,85)$. Interestingly, this chemokine is constitutively expressed in the lung $(18,127)$. These observations strongly suggested that CXCR6 contributes to both active and basal recruitment of $\mathrm{CD}^{+} \mathrm{T}$ cells to the lung.

\section{Temporal Retention and Positioning of $\mathrm{CD8}^{+} \mathbf{T}$ Cells in the Lung}

\section{Inhibition of tissue egress}

It is well known that sphingosine 1-phosphate (S1P) plays a key role in the egress of lymphocytes from the lymph nodes and thymus $(4,86)$, and recent studies indicate that this is also the case for the nonlymphoid tissues $(71,78,115,123) . \mathrm{S} 1 \mathrm{P}$ is present at high levels in the blood and lymph, which results in the continuous downregulation of its receptor S1P receptor-1 $\left(\mathrm{S}_{1} \mathrm{P}_{1}\right)$ on circulating $\mathrm{T}$ cells $(102,110)$. Upon tissue entry, $\mathrm{CD}^{+} \mathrm{T}$ cells instantly recover surface expression of $\mathrm{S}_{\mathrm{P}} \mathrm{P}_{1}$ due to the relatively low concentration of S1P in the parenchymal tissues (15) and are thereby subjected to opposite chemotaxis toward the lymphatics $(78,115)$. Hence, a balance between the S1P-mediated exit signal and the chemokine-mediated migratory signals controls the direction of $\mathrm{T}$ cell migration, which potentially reflects the differential dynamics between $\mathrm{T}_{\mathrm{EM}}$ and $\mathrm{T}_{\mathrm{RM}}$ cells within the peripheral tissues.

The $\mathrm{T}$ cell expression of $\mathrm{S}_{1} \mathrm{P}_{1}$ is regulated by at least two distinct mechanisms: local cytokine-induced transcriptional downregulation of S1prl, which encodes $\mathrm{S}_{1} \mathrm{P}_{1}(115)$, and the activation maker CD69-mediated posttranscriptional antagonism $(8,114)$. Under the basal recruitment (in the absence of strong chemokine signaling in the tissues), forced expression of $\mathrm{S}_{1} \mathrm{P}_{1}$ or genetic deletion of CD69 results in the significant loss of tissue-circulating $\mathrm{CD}^{+} \mathrm{T}$ cells as well as $\mathrm{CD}^{+} \mathrm{T}_{\mathrm{RM}}$ precursors in the nonlymphoid tissues, including the lung $(78,115,123)$, which is likely due to the accelerated tissue egress mediated by $\mathrm{S}_{1} \mathrm{P}_{1}$. Importantly, although pharmacological inhibition of $\mathrm{S}_{1} \mathrm{P}_{1}$ by the agonist FTY720 leads to transient accumulation of $\mathrm{CD} 69^{-} \mathrm{CD} 8^{+} \mathrm{T}$ cells in the lung, this was reversed when FTY720 treatment was discontinued (123). These findings suggest that $\mathrm{T}$ cells are committed to leave tissues during steady-state conditions, unless $\mathrm{S}_{1} \mathrm{P}_{1}$ expression is inhibited. Since recruitment of $\mathrm{CD}^{+} \mathrm{T}$ cells into the lung does not lead to the downregulation of Klf2 or its downstream target S1prl (123), local reactivation and subsequent upregulation of CD69 are likely crucial for the temporal retention of tissue-circulating $\mathrm{CD}^{+} \mathrm{T}$ cells in the lung under the basal recruitment conditions (Fig. 1). In contrast, we have demonstrated that this is not the case during the acute phase of infection where the lack of CD69 has a little impact on the active recruitment of effector $\mathrm{CD}^{+} \mathrm{T}$ cells to the lung unless a CD69-intact wildtype competitor $\mathrm{T}$ cell is present (123). Thus, during the acute phase of infection, inflammation-induced chemotactic signaling overrides the S1P-mediated exit signal, which may explain the appearance of $\mathrm{CD}^{+} \mathrm{T}$ cells specific for unrelated antigens in the lung $(23,123)$.

CCR7 is also known to regulate the egress of effector $\mathrm{CD}^{+}$cells from the lung interstitium through the lymph $(12,19,56)$. This is consistent with the fact that activated respiratory DCs migrate to the MLN in a CCR7-dependent manner $(39,42)$. As is the case with $\mathrm{S}_{1} \mathrm{P}_{1}$, antigen recognition in the lung leads to downregulation of CCR7 on effector 
$\mathrm{CD}^{+} \mathrm{T}$ cells, suggesting that $\mathrm{S}_{1} \mathrm{P}_{1}$ and CCR7 cooperatively accelerate the egress of antigen-specific $\mathrm{CD}^{+} \mathrm{T}$ cells from the lung. It is also noteworthy that antigen-dependent selective retention of effector $\mathrm{CD} 8^{+} \mathrm{T}$ cells may prevent overt pathogenesis by decreasing the number of bystander $\mathrm{T}$ cells at the site of infection (56). However, as most CCR7 should be already downregulated when expanded effector $\mathrm{CD}^{+} \mathrm{T}$ cells leave the MLN and all of previous data were analyzed in the presence of large proportions of cell contaminants in the blood, analysis using i.v. staining would be required to precisely understand the role of this chemokine receptor.

\section{Integrin-mediated retention in the specific microenvironment of the lung}

In addition to CD69, high levels of integrin $\alpha 1 \beta 1$ (VLA-1: very late antigen-1) and $\alpha \mathrm{E} \beta 7$ (detected by CD49a and CD103, respectively) expression are unique hallmarks of $\mathrm{CD}^{+} \mathrm{T}_{\mathrm{RM}}$ cells in the lung compared to circulatory memory $\mathrm{CD}^{+} \mathrm{T}$ cell populations in the lymphoid and nonlymphoid tissues, including $\mathrm{T}_{\mathrm{EM}}$ cells in the lung (123). VLA-1 preferentially binds to type IV and type I collagen $(40,58,128)$. Type IV collagen constitutes the major structural component of basement membranes of the vascular endothelium and airway epithelium, while type I collagen is widely distributed in the lung interstitium (104). In contrast, integrin $\alpha \mathrm{E} \beta 7$ binds to E-cadherin, which forms adherens junctions between lung airway epithelial cells (98). Analyses using blockade antibodies or knockout mice have revealed that both VLA-1 and integrin $\alpha \mathrm{E} \beta 7$ are not required for the active recruitment of $\mathrm{CD}^{+} \mathrm{T}$ cells to the lung $(74,103)$. Instead, these integrins fine-tune the distribution of migrant $\mathrm{CD}^{+} \mathrm{T}$ cells within the lung. For example, VLA-1 promotes distribution of cells in close proximity to the basement membranes of the blood vessels as well as the airways $(103,104)$. The binding of VLA-1 to type IV collagen, in combination with signaling through tumor necrotic factor (TNF) receptor II, also protects effector $\mathrm{CD}^{+} \mathrm{T}$ cells in the airways from apoptosis during the acute phase of infection (105). Interestingly, compared to effector $\mathrm{CD}^{+} \mathrm{T}$ cells, effector $\mathrm{CD}^{+} \mathrm{T}$ cells recruited to the lung exhibit lower VLA-1, but higher VLA-2 (integrin $\alpha 2 \beta 1$ detected by $\mathrm{CD} 49 \mathrm{~b}$ ), which prefer type I, but not type IV collagen, allowing $\mathrm{CD}^{+} \mathrm{T}$ cells to localize preferentially in the lung interstitium, but not in the airways (104). Integrin $\alpha \mathrm{E} \beta 7$ also promotes retention of effector $\mathrm{CD}^{+} \mathrm{T}$ cells in the lung airways $(51,74)$. It is important to note, however, that such integrin-mediated retention signals are likely redundant or supportive as the lack of one of those integrins does not lead to the significant loss of effector $\mathrm{CD}^{+} \mathrm{T}$ cells in the lung airways $(74,103)$.

It is currently unclear what signals are responsible for the upregulation of VLA-1 on $\mathrm{CD}^{+} \mathrm{T}$ cells. Antigen-specific $\mathrm{CD}^{+} \mathrm{T}$ cells in nonlymphoid tissues are mostly VLA-1 ${ }^{+}$, indicating the universal role of this integrin in the retention of cells that are "basally" recruited to the nonlymphoid tissues (103). Interestingly, large numbers of VLA- $1^{+} \mathrm{CD}^{+}$ $\mathrm{T}$ cells accumulate in the lung following respiratory, but not systemic infections/vaccinations $(108,123)$. Furthermore, local inflammation in the presence of cognate antigen, but not inflammation alone, enables the conversion of circulating $\mathrm{CD}^{+} \mathrm{T}$ cells into VLA- $1^{+} \mathrm{CD}^{+} \mathrm{T}_{\mathrm{RM}}$ cells in the lung
(123), suggesting the impact of local reactivation on the upregulation or maintenance of VLA-1 expression on actively recruited $\mathrm{CD}^{+} \mathrm{T}$ cells to the inflamed nonlymphoid tissues. In support of this, CD49a expression defines a marker of $\mathrm{CD}^{+} \mathrm{T}_{\mathrm{RM}}$ cells having a highly cytolytic potential (13). However, additional experiments are required to precisely resolve the question where and when upregulation of VLA-1 occurs. On the other hand, transforming growth factor- $\beta$ (TGF- $\beta$ ) signaling is known to be necessary for the upregulation of integrin $\alpha \mathrm{E} \beta 7$ as lack of this signal results in the complete loss of $\mathrm{CD} 103^{+} \mathrm{CD}^{+} \mathrm{T}$ cells in the lung (51,133). $\mathrm{CD}^{+} \mathrm{T}$ cell-derived interferon- $\gamma$ (IFN- $\gamma$ ) potentially contributes to the secretion of TGF- $\beta$ in the lung, thereby helping $\mathrm{CD}^{+} \mathrm{T}$ cell retention in the airways by inducing the expression of CD103 (70). Based on these data, the upregulation of integrins in the lung and the consequential regulation of tissue distribution of the effector $\mathrm{T}$ cells could also be considered a consequence of local tissuederived instruction that promotes $\mathrm{T}_{\mathrm{RM}}$ differentiation.

\section{Differentiation of Lung CD8 ${ }^{+} \mathbf{T}_{\mathrm{RM}}$ Cells}

\section{Second hit with cognate antigen in the lung}

It is well established that effector $\mathrm{CD}^{+} \mathrm{T}$ cells recruited to the lung subsequently encounter respiratory DC subsets that present cognate antigen. This "second hit" with cognate antigen at the site of infection improves the cell capacity to secrete IFN- $\gamma(88)$ and induces additional rounds of proliferation (87). In addition to stimulating the $\mathrm{CD}^{+} \mathrm{T}$ cells, respiratory DCs trans-present IL-15 to prevent rapid apoptosis of the cells (89). While these antigen stimulation processes regulate terminal effector differentiation, several studies have indicated that local antigen recognition also serves as a primary tissue-derived instructive factor requisite for effective $\mathrm{T}_{\mathrm{RM}}$ differentiation $(9,59,90,97,123,133)$.

In the case of surface and mucosal tissues, such as skin and vagina, $\mathrm{CD}^{+} \mathrm{T}_{\mathrm{RM}}$ cells can be generated independent of cognate antigen. For example, forced recruitment of cells to the epithelial tissues by antigen-independent local inflammation or topical chemokine administration results in the establishment of $\mathrm{CD}^{+} \mathrm{T}_{\mathrm{RM}}$ cells $(81,113)$, a method known as "prime-pull." Furthermore, basal levels of $\mathrm{CD}^{+} \mathrm{T}_{\mathrm{RM}}$ cells can be deposited in multiple nonlymphoid tissues even after systemic infection in the absence of any local antigen presentation or inflammation $(115,119)$. It should be noted that such bystander deposition of $\mathrm{CD}^{+} \mathrm{T}_{\mathrm{RM}}$ cells does not occur in the lung. As we have recently demonstrated, $\mathrm{CD}^{+} \mathrm{T}$ cells actively recruited to the lung by antigen-independent inflammation completely disappear after resolution of inflammation in the lung (123). In contrast, the combination of local inflammation and cognate antigen successfully promotes lung $\mathrm{CD}^{+} \mathrm{T}_{\mathrm{RM}}$ cell development (123). Thus, the lung is a unique tissue where local antigen is required for the establishment of $\mathrm{CD}^{+} \mathrm{T}_{\mathrm{RM}}$ cells. This appears to be based on the structural differences between lung and other surface/mucosal tissues, which will be discussed in detail later. Despite the fact that $\mathrm{CD}^{+} \mathrm{T}_{\mathrm{RM}}$ cells can be established in the skin independent of cognate antigen, there is a significant increase in the $T_{R M}$ formation when antigen is present $(59,97)$, indicating that although local antigen recognition is not necessary for the establishment of $\mathrm{T}_{\mathrm{RM}}$ in all tissues, it nevertheless enhances $\mathrm{T}_{\mathrm{RM}}$ deposition. Hence, a second hit with cognate antigen in the 
peripheral tissues plays a key role not only for terminal effector differentiation but also function as pivotal tissue instruction for $\mathrm{T}_{\mathrm{RM}}$ differentiation.

It is not understood how signals elicited by the local antigen can induce either terminal effector differentiation or $\mathrm{T}_{\mathrm{RM}}$ development. How is this decision checkpoint regulated? There are at least four potential explanations. First, the decision to become a terminal effector or $\mathrm{T}_{\mathrm{RM}}$ cell following local reactivation may be cell-intrinsically precommitted before recruitment, perhaps reflecting whether the cells originated from short-lived effector cells (SLECs) or memory precursor effector cells (MPECs) $(57,80)$. Second, as previously described, a division of labor between respiratory DC subsets may also take place even within the lung, as CD $103^{+}$DCs, but not CD $11 b^{\mathrm{hi}}$ DCs, preferentially drive CD103 expression upon $\mathrm{CD}^{+} \mathrm{T}$ cell activation (133). Third, fate decisions between terminal effector and $\mathrm{T}_{\mathrm{RM}}$ may be determined by temporal deviation of reactivation (16). For example, in the case of $\mathrm{CD}^{+} \mathrm{T}$ cells, McKinstry et al. have shown that late antigen recognition, which is necessary for memory formation, occurred at days 5-8 postinfection, and have termed this time window as the "memory check point" (90). Whereas a second hit for terminal effector differentiation may occur a little earlier, as cognate antigen-presenting respiratory DCs were transferred intranasally on day 3 and analyzed by day 5 (88). Actually, this third hypothesis is mainly attributed to the fourth hypothesis in which effector versus memory fate decision may be regulated by the strength of $\mathrm{CD}^{+} \mathrm{T}$ cell activation. Both, the levels of antigen presentation (17) as well as the levels of the "third signal" induced by inflammatory cytokines (14) influence the activation status. Such antigenic as well as inflammatory signals may be redundant at early phases of infection, which bias $\mathrm{CD}^{+} \mathrm{T}$ cell differentiation toward terminal effector cells, while weak signaling at later time points preferentially promotes memory differentiation (16). Distinct microdistribution of $\mathrm{CD}^{+} \mathrm{T}$ cells also influences differential acquisition of the activation signals. For example, CXCR $3^{\text {hi }}$ cells receive stronger stimulatory signals and preferentially become terminal effectors, while lack of this receptor puts cells away from the core of inflammatory microenvironment, and ultimately promotes memory differentiation $(50,66,69)$. All those factors must cooperatively regulate $\mathrm{CD}^{+} \mathrm{T}$ cell fate following late antigen recognition.

There is strong evidence that $\mathrm{CD}^{+} \mathrm{T}_{\mathrm{RM}}$ precursors receive bona fide TCR signaling in the peripheral tissues since the cells exhibit high levels of Nur77 expression $(9,59)$. However, the molecular mechanisms by which TCR signalinginduced events elicit $\mathrm{T}_{\mathrm{RM}}$ formation remain unclear. $\mathrm{CD} 4^{+} \mathrm{T}$ cells produce IL- 2 in response to late antigen recognition, and autocrine IL-2 signaling at the memory check point improves memory CD4 T cell survival in the spleen, MLN, and lung, (90) suggesting it as a potential mechanism. Another observation is that inhibition of the mammalian target of rapamycin (mTOR) during the early phase of infection selectively impairs the formation of $\mathrm{CD}^{+} \mathrm{T}_{\mathrm{RM}}$ cells in the small intestine, while simultaneously enhancing memory generation in the spleen (118), suggesting that mTOR expression in response to local reactivation may play a role in the $T_{R M}$ differentiation by modulating the metabolic status. Clearly, a great deal more study is required to understand how local antigen restimulation optimizes $\mathrm{CD}^{+} \mathrm{T}_{\mathrm{RM}}$ formation.

\section{Local cytokine-mediated instruction}

In addition to late antigen recognition, local cytokine signaling is also crucial for the formation of $\mathrm{CD}^{+} \mathrm{T}_{\mathrm{RM}}$ cells in the lung. TGF- $\beta$ is produced by a wide variety of cell types in the lung, including alveolar macrophages, neutrophils, activated alveolar epithelial cells and endothelial cells (31). Although TGF- $\beta$ is known as a profibrotic cytokine and its overproduction is critically associated with pulmonary fibrosis (31), influenza virus-infected animals recover without the acquisition of lung fibrosis $(68,123)$, suggesting that TGF$\beta$ production as well as its activation is rather stable during the course of infection. This is true despite the fact that some strains of influenza virus surface protein can activate latent TGF- $\beta$ in the lung (109). Local TGF- $\beta$ signaling does not require Sma- and Mad-related protein 4 (Smad4) (51), and plays a key role in the downregulation of T-box transcription factors Eomes and T-bet in effector $\mathrm{CD}^{+} \mathrm{T}$ cells, both of which are required for effector to $T_{R M}$ transition (82). Upon skin $\mathrm{CD}^{+} \mathrm{T}_{\mathrm{RM}}$ differentiation, Eomes expression is fully extinguished, while T-box expression remains at a low level, which sustains CD122 expression (IL-15 receptor $\beta$-chain) and enables to receive IL-15-medaited survival signal (82). As T-bet imposes repression of CD103, the downregulation of T-bet reciprocally leads to the expression of integrin $\alpha \mathrm{E} \beta 7$.

Although the requirement of TGF- $\beta$ in $\mathrm{T}_{\mathrm{RM}}$ differentiation seems universal for all nonlymphoid tissues, IL-15 may not be essential for the establishment of $\mathrm{CD}^{+} \mathrm{T}_{\mathrm{RM}}$ cells in the lung. In fact, IL-15 production is increased especially in cells purified from the airways and also the lung tissues following influenza virus infection, and lack of IL-15 results in transient reduction in the number of effector $\mathrm{CD}^{+} \mathrm{T}$ cells in the airways at the early phase of infection (7-12 days) (130). However, such reduction is no longer observed at the memory phase of infection without any treatment (131), indicating that the lack of IL-15 essentially has no impact on the ultimate generation of $\mathrm{CD}^{+} \mathrm{T}_{\mathrm{RM}}$ cells in the lung.

At later time points during an acute virus infection (around day 7), effector $\mathrm{CD}^{+} \mathrm{T}$ cells recruited to the lung produce a significant amount of IL-10 in response to CD $4^{+} \mathrm{T}$ cell-derived IL-2 and innate lymphoid cell-derived IL-27 $(101,120,121)$. $\mathrm{CD}^{+} \mathrm{T}$ cell production of IL-10 is correlated with its terminal maturation and is vital in preventing excess inflammation in the lung (121). Since IL-10 induces activation of the signal transducer and activator of transcription 3 (STAT3) that promotes memory $\mathrm{CD}^{+} \mathrm{T}$ cell differentiation, it is tempting to speculate that IL-10 produced by terminal effector $\mathrm{CD}^{+} \mathrm{T}$ cells at the memory check point may impact neighbor as well as late-comer $\mathrm{CD} 8^{+} \mathrm{T}_{\mathrm{RM}}$ precursors, and promote memory maturation in the lung.

\section{Niche-dependent establishment of $C D 8^{+} T_{R M}$ cells in the lung}

In the case of skin, $\mathrm{CD}^{+} \mathrm{T}_{\mathrm{RM}}$ precursors recruited to the skin persist in an epidermal niche that is originally occupied by dendritic epidermal $\gamma \delta \mathrm{T}$ cells (DETCs). This results in their lifelong persistence (137). Because normal lung tissues do not exhibit such preformed niches to displace, additional "space" is required for the cells to inhabit. It has long been believed that lung $\mathrm{CD}^{+} \mathrm{T}_{\mathrm{RM}}$ cells are maintained in the ectopic lymphoid tissues developed in response to respiratory virus infections, such as inducible bronchus-associated 
lymphoid tissues (iBALT) (95). However, our group has demonstrated that such structures are primarily populated with $\mathrm{CD}^{+} \mathrm{T}$ cells as well as $\mathrm{B}$ cells, but relatively few numbers of $\mathrm{CD}^{+} \mathrm{T}$ cells (123). Rather, $\mathrm{CD}^{+} \mathrm{T}_{\mathrm{RM}}$ cells are enriched specifically in niches created at the site of tissue regeneration after injury, which are termed as repair-associated memory depots (RAMDs) (123). Histologically, RAMDs represent confluent foci of peribronchiolar lymphocytic infiltrates with diffuse thickening of alveolar walls in surrounding area. Thus, the niches exist primarily in the lung interstitium with partial extension to the lung parenchyma. The appearance of cytokeratin-expressing cell aggregates, known as Krt pots, is a unique hallmark of RAMDs. Krt pots comprise distal airway stem cells that begin to emerge in the lung around day 7 postinfection, proliferate vigorously, and subsequently differentiate and reconstruct the damaged lung tissues $(68,129,140)$. However, it is unclear whether those cells directly impact the differentiation of $\mathrm{CD}^{+} \mathrm{T}_{\mathrm{RM}}$ cells. $\mathrm{CD} 8^{+} \mathrm{T}_{\mathrm{RM}}$ cells in the RAMDs do not form a specific organized structure and are simply sequestered in this site, while $\mathrm{CD}^{+} \mathrm{T}_{\mathrm{RM}}$ cells in the iBALT typically form clusters and surround B cell follicles (123). Such distinct distributions between $\mathrm{CD}^{+}$and $\mathrm{CD} 4^{+}$ $\mathrm{T}_{\mathrm{RM}}$ cells in the lung clearly reflect their division of labor upon recall, in which $\mathrm{CD} 8^{+} \mathrm{T}_{\mathrm{RM}}$ cells exert their function as cytotoxic $\mathrm{T}$ lymphocytes (CTLs) at the damaged site, while $\mathrm{CD} 4^{+}$ $T_{R M}$ cells and $B$ cells need to interact with each other in the iBALT for sustained germinal center formation (3). There is also rigid compartmentalization between lung $\mathrm{CD} 8^{+} \mathrm{T}_{\mathrm{RM}}$ cells and $\mathrm{CD} 8^{+} \mathrm{T}_{\mathrm{EM}}$ cells that circulate between the lung and blood. For instance, $\mathrm{CD} 8^{+} \mathrm{T}_{\mathrm{EM}}$ cells in the lung are widely, but sparsely distributed in the unaffected lung interstitium, and never involved in the RAMDs unless de novo niches are newly created (123). As described previously, $\mathrm{CD} 8^{+} \mathrm{T}_{\mathrm{EM}}$ cells exit lung tissues mainly through S1P-induced chemotaxis to the lymph. In contrast, inhibition of $\mathrm{S}_{1} \mathrm{P}_{1}$ is no longer required for the retention of $\mathrm{CD} 8^{+} \mathrm{T}_{\mathrm{RM}}$ cells in the RAMDs due, in part, to limited access to S1P gradient in this microenvironment (123). Importantly, not only tissue-circulating $\mathrm{CD}^{+} \mathrm{T}_{\mathrm{EM}}$ cells but also effector $\mathrm{CD} 8^{+} \mathrm{T}$ cells are incapable of being involved in the RAMDs later than the peak of $\mathrm{CD} 8^{+} \mathrm{T}$ cell response in the lung (around day 10, which also reflects the peak of tissue damage) (123). Because administration of cognate antigen in combination with the prime-pull strategy enables de novo creation of the RAMD and subsequent establishment of CD8 ${ }^{+}$ $\mathrm{T}_{\mathrm{RM}}$ cells in the lung (123), the availability of cognate APCs in the RAMDs likely restricts the numbers of $\mathrm{CD}^{+} \mathrm{T}$ cells deposited. Indeed, there is a competition among antigen-specific effector $\mathrm{CD}^{+} \mathrm{T}$ cells to interact with cognate APCs in the inflamed microenvironment (97). Interestingly, this competition occurs even between effector $\mathrm{CD}^{+} \mathrm{T}$ cells with distinct specificities when epitopes specific for those effectors are presented on the same DCs, thereby shaping the local repertoire (97). Such conventional- as well as cross-competition of local antigens may explain the selective deposition of $\mathrm{CD} 8^{+} \mathrm{T}_{\mathrm{RM}}$ cells expressing high-affinity TCRs (32).

\section{Maintenance of Lung $\mathrm{CD8}^{+} \mathrm{T}_{\mathrm{RM}}$ Cells}

\section{$A$ revised theory on continual recruitment and permanent deposition}

A primary definition of $T_{R M}$ cells is that they are maintained in the lymphoid and nonlymphoid tissues without recirculation. This definition clearly applies to lung airway memory $\mathrm{CD}^{+} \mathrm{T}$ cells because, once recruited, those cells do not return to the circulation or the lung interstitium (47). However, maintenance of this population differs significantly from that of $\mathrm{CD}^{+} \mathrm{T}_{\mathrm{RM}}$ cells in other mucosal tissues. For example, although lung airway memory $\mathrm{CD} 8^{+} \mathrm{T}$ cells are not highly apoptotic, it has demonstrated that the half-life of this population is $\sim 2$ weeks (24). Such a short lifespan is likely due to the biophysical effects of the harsh airway environment: cells are being cleared by phagocytic cells or removed through mucociliary clearance. Furthermore, airway memory $\mathrm{CD}^{+} \mathrm{T}$ cells do not proliferate (47). Based on these findings, a concept emerged that memory $\mathrm{CD} 8^{+} \mathrm{T}$ cells in the airways are continuously replaced by new cells recruited from the circulation as a process of memory $\mathrm{T}$ cell maintenance. This was confirmed by the continuous appearance of LFA- $1^{+}$cells in the airways even in the situation that memory $\mathrm{CD} 8^{+} \mathrm{T}$ cells downregulate LFA-1 within $48 \mathrm{~h}$ after entry into the airways (24). Importantly, however, our recent findings have confirmed that only a limited number of cells in the lung airways are continually replaced by cells from the circulation. In brief, ratios of memory $\mathrm{CD} 8^{+} \mathrm{T}$ cells recruited from the circulation to the airways peaked at only $\sim 20 \%$ by 2 weeks after parabiotic surgery, and this ratio was maintained for up to 7 weeks (123). Thus, while $\sim 20 \%$ of memory $\mathrm{CD}^{+} \mathrm{T}$ cells in the airways are new recruits, $\sim 80 \%$ are obviously segregated from blood-born memory $\mathrm{CD} 8^{+} \mathrm{T}$ cells, just like $\mathrm{T}_{\mathrm{RM}}$ cells in other mucosal tissues. This raised a question whether the latter cell population can survive for long in the harsh airway environment. We speculate that continual recruitment is also essential for $\sim 80 \%$ of memory $\mathrm{CD}^{+} \mathrm{T}$ cells in the airways. If this is the case, their source may be $\mathrm{CD} 8^{+} \mathrm{T}_{\mathrm{RM}}$ pools in the lung interstitium/parenchyma, but not memory $\mathrm{CD} 8^{+} \mathrm{T}$ cells in the circulation (Fig. 1).

As is the case with cells in the lung airways, memory $\mathrm{CD} 8^{+}$ $\mathrm{T}$ cells in the lung interstitium/parenchyma consist of at least two distinct memory $\mathrm{T}$ cell subpopulations: $\sim 80 \%$ bona fide $\mathrm{T}_{\mathrm{RM}}$ cells present in the RAMDs and $\sim 20 \% \mathrm{~T}_{\mathrm{EM}}$ cells present the lung interstitium (123) (Fig. 1). In the steady state in the lung, there is a balance between basal recruitment-mediated influx and S1P-mediated efflux through the lymph that maintains the flat ratio of $\mathrm{CD}^{+} \mathrm{T}_{\mathrm{EM}}$ cells (Fig. 1). We hypothesize that a small fraction of cells are activated by antigen-independent inflammatory stimuli, potentially due to exposure with airborne contaminants. These cells upregulate CD69 expression, causing them to transiently persist in the interstitium, and some of them are then recruited to the airways through a process of basal recruitment (Fig. 1). The mechanisms by which $\mathrm{CD}^{+} \mathrm{T}_{\mathrm{RM}}$ cells in the RAMDs are maintained remain unclear with possibilities, including homeostatic proliferation or prolonged longevity. There is evidence that $\mathrm{CD}^{+} \mathrm{T}_{\mathrm{RM}}$ cells in the lung interstitium/ parenchyma and airways are maintained independent of homeostatic cytokine IL-15 (131). This is consistent with the relatively lower level of expression of IL-15 receptor $\beta$ on memory $\mathrm{CD}^{+} \mathrm{T}$ cells in the lung compared to those in the spleen (112). Nevertheless, these findings do not exclude a possibility that other factors may drive homeostatic turnover of $\mathrm{CD}^{+} \mathrm{T}_{\mathrm{RM}}$ cells in the lung RAMDs, such as residual antigen-induced reactivation. Although numerous questions remain in this field, the discovery of specific niches in the lung interstitium/parenchyma has substantial implications in 
understanding the factors regulating the maintenance of $\mathrm{CD} 8^{+}$ $\mathrm{T}_{\mathrm{RM}}$ cells in the lung.

\section{Niches and residual antigen: factors that potentially restrict the numbers of $C D 8^{+} T_{R M}$ cells maintained in the lung}

Following a respiratory virus infection, the number of antigen-specific $\mathrm{CD}^{+} \mathrm{T}$ cells in the lung peaks on day 10 and then declines dramatically as infection subsides. This is followed by the establishment of $\mathrm{CD}^{+} \mathrm{T}_{\mathrm{RM}}$ cells at around 1 month postinfection. The absolute number of $\mathrm{CD}^{+} \mathrm{T}_{\mathrm{RM}}$ cells in the lung wanes over time, which results in a decrease in the protective efficacy of these cells against secondary infection with a homologous virus (67). For example, $\mathrm{CD}^{+}$ $\mathrm{T}_{\mathrm{RM}}$ cell-mediated protective immunity is essentially lost at 4-6 months postinfection (135). This contrasts with the situation in the skin where $\mathrm{CD}^{+} \mathrm{T}_{\mathrm{RM}}$ cells can persist up to 1 year (137). The shorter lifespan of lung $\mathrm{CD}^{+} \mathrm{T}_{\mathrm{RM}}$ cells could be explained by our recent findings regarding the niche-dependent maintenance of $\mathrm{CD}^{+} \mathrm{T}_{\mathrm{RM}}$ cells in the lung (123). As described above, $\mathrm{CD}^{+} \mathrm{T}_{\mathrm{RM}}$ cells are predominantly accumulated in the RAMDs: disorganized peribronchiolar foci that are temporarily created at the site of tissue damage. In fact, peribronchiolar foci still remain in the lung at a month postinfection, despite the fact that inflammatory responses have largely abated at this time point. As tissue regeneration proceeds, the size of the RAMDs shrinks over time and tends to disappear several months postinfection. Thus, we suggest that the decrease in numbers of $\mathrm{CD}^{+}$ $\mathrm{T}_{\mathrm{RM}}$ cells in the lung for the first couple of months simply depends on the size of the RAMDs. We also suggest that an organized lymphoid structure like iBALT persists for longer periods and low numbers of $\mathrm{CD}^{+} \mathrm{T}_{\mathrm{RM}}$ cells persist in the iBALT following disappearance of RAMDs. This hypothesis is based on the idea that lung tissues do not initially have preexisted niches in which $\mathrm{T}$ cells can persist. Thus, the progressive loss of temporarily created "spaces" significantly restricts the long-term maintenance of $\mathrm{CD}^{+} \mathrm{T}_{\mathrm{RM}}$ cells.

As discussed above, cognate antigen that remains in the RAMDs is also a potential factor regulating the number of $\mathrm{CD}^{+} \mathrm{T}_{\mathrm{RM}}$ cells in the lung. In fact, viral antigen can be detected in the peribronchiolar lymphocytic infiltrates (62) as well as bronchial epithelial cells (41) at least a month postinfection. Furthermore, $\mathrm{CD}^{+} \mathrm{T}_{\mathrm{RM}}$ cells, but not $\mathrm{T}_{\mathrm{EM}}$ cells, express CD69 as well as PD-1, indicative of recent activation $(123,135)$. Those observations suggest that residual antigen presentation is limited in the RAMDs, but not in the unaffected lung interstitium. Thus, the reduced $\mathrm{CD}^{+}$ $\mathrm{T}_{\mathrm{RM}}$ persistence in the RAMDs is also potentially caused by reduction in the level of residual antigen presentation. Importantly, despite the fact that PD-1 impairs the protective efficacy of memory $\mathrm{CD}^{+} \mathrm{T}$ cells in the lung $(28,92)$, accumulating evidence suggests that these cells never succumb to functional exhaustion $(25,44)$. Thus, the level of residual antigen presentation must be lower than that exhibited during a typical chronic infection. In line with this, PD-1 as well as other potential inhibitory molecules may act to prevent excessive immunopathology $(26,27,29)$ by maintaining the cells in a quiescent state (49). Furthermore, reactivation of $\mathrm{CD}^{+}$ $\mathrm{T}_{\mathrm{RM}}$ cells in the lung leads to sustained expression of interferon-induced transmembrane protein (IFITM3), which is involved in conferring resistance against subsequent virus infection (132). Hence, in contrast to chronic infection, the repeated acquisition of weak cognate signals may be beneficial rather than harmful for the maintenance of $\mathrm{CD} 8^{+} \mathrm{T}_{\mathrm{RM}}$ cells in the lung. A remaining question is how APCs avoid being eliminated by antigen-specific $\mathrm{CD}^{+} \mathrm{T}_{\mathrm{RM}}$ cells. It is tempting to hypothesize that PD-1-mediated partial inhibition may play a role in this escape without inducing the global exhaustion.

It has also demonstrated that residual antigen presentation persists in the MLN for several months after acute respiratory virus infections $(54,55,62,75,122,138)$. Because memory $\mathrm{CD}^{+} \mathrm{T}$ cells in the MLN and the lung airways exhibit similar activated phenotypes, it has been suggested that reactivation by residual antigen in the MLN induces the migration of memory $\mathrm{CD}^{+} \mathrm{T}$ cells from the MLN to the lung airways, resulting in the continual influx of cells to the airways (138). In other words, reactivation in the MLN induces phonotypic changes in memory $\mathrm{T}$ cells from lymph node-surveying $\mathrm{T}_{\mathrm{CM}}$ to peripheral tissue homing $\mathrm{T}_{\mathrm{EM}}$ cells $(122,138)$. However, it should be noted that the basal levels of continual recruitment of cells to the airways also occur in the absence of residual antigen (65). Furthermore, memory $\mathrm{CD}^{+} \mathrm{T}$ cells in the circulation gradually lose the expressions of Blimp-1 and Hobit (117), key transcription factors regulating tissue retention (79). As a result, the efficacy of continual (basal) recruitment to the airways wanes over time (117). One should also be mindful of the fact that signature markers of $\mathrm{T}_{\mathrm{RM}}$ cells, such as CD69 and CD103, could be upregulated on lung-circulating blood-born $\mathrm{CD}^{+} \mathrm{T}_{\mathrm{EM}}$ cells in certain tissue environments (65) or basal levels of TNF secreted in the lung (117). However, it is still unclear whether $\mathrm{T}_{\mathrm{EM}^{-} \text {-derived CD69 }}{ }^{+} \mathrm{CD} 103^{+}$cells acquire certain tissue residency. $(117,123)$ Thus, a more precise analysis of migratory property is required to define $\mathrm{CD}^{+} \mathrm{T}_{\mathrm{RM}}$ cells in the lung. Nevertheless, lung-circulating $\mathrm{CD}^{+} \mathrm{T}_{\mathrm{EM}}$ cell populations should not be neglected as those populations could be majority when bona fide $\mathrm{T}_{\mathrm{RM}}$ cells disappeared (117), and have an ability to contribute, in part, to the protective immunity upon rechallenge (116).

\section{Concluding Remarks}

Ultimately, a better understanding of CD8 memory in the lung is essential for the development of safe and effective vaccines capable of generating long-lasting antigen-specific memory $\mathrm{CD}^{+} \mathrm{T}$ cells. Despite a great deal of progress in understanding $\mathrm{CD}^{+} \mathrm{T}$ cell memory in the lung and recent success in generating lung $\mathrm{CD}^{+} \mathrm{T}_{\mathrm{RM}}$ cells by vaccination $(37,133,139)$, our identification of specific niches for $\mathrm{CD}^{+}$ $\mathrm{T}_{\mathrm{RM}}$ cells in the lung and other data raises a fundamental possibility that lung $\mathrm{CD} 8^{+} \mathrm{T}_{\mathrm{RM}}$ cells are by necessity short lived (e.g., several months). This is primarily due to the lack of preexisting $\mathrm{CD}^{+} \mathrm{T}_{\mathrm{RM}}$ niches in the lung and the shortlived nature of these niches. Furthermore, peribronchiolar foci fill alveolar spaces, thereby reducing the efficacy of gas exchange, indicating that a risk (tissue damage and resultant functional impairment) is unavoidable to create niches for lung $\mathrm{CD}^{+} \mathrm{T}_{\mathrm{RM}}$ cells. Thus, long-term maintenance of $\mathrm{CD}^{+}$ $\mathrm{T}_{\mathrm{RM}}$ cells in the lung and repeated tissue damage are two sides of the same coin, and future study should be focused on the balance between protective efficacy and immune 
pathology when considering the vaccines that target $\mathrm{CD} 8^{+}$ $\mathrm{T}_{\mathrm{RM}}$ cells in the lung.

\section{Acknowledgments}

We thank Dr. Tomoya Katakai (Niigata University) for helpful discussions. This work is supported by Grant-in-Aid for Young Scientists (A) 24689043, and Grant-in-Aid for Scientific Research (C) 16K08850 from Ministry of Education, Culture, Sports, Science and Technology of Japan, and grants from Takeda Science Foundation, Daiichi-Sankyo Foundation of Life Science, Uehara Memorial Foundation, Kanae Foundation for the Promotion of Medical Science, The Waksman Foundation of Japan, Kato Memorial Bioscience Foundation, and Mochida Memorial Foundation for Medical and Pharmaceutical Research.

\section{Author Disclosure Statement}

No competing financial interests exist.

\section{References}

1. Abboud G, Desai P, Dastmalchi F, et al. Tissue-specific programming of memory CD8 $\mathrm{T}$ cell subsets impacts protection against lethal respiratory virus infection. J Exp Med 2016;213:2897-2911.

2. Abel S, Hundhausen $\mathrm{C}$, Mentlein $\mathrm{R}$, et al. The transmembrane CXC-chemokine ligand 16 is induced by IFNgamma and TNF-alpha and shed by the activity of the disintegrin-like metalloproteinase ADAM10. J Immunol 2004;172:6362-6372.

3. Adachi Y, Onodera T, Yamada Y, et al. Distinct germinal center selection at local sites shapes memory B cell response to viral escape. J Exp Med 2015;212:1709-1723.

4. Allende ML, Dreier JL, Mandala S, and Proia RL. Expression of the sphingosine 1-phosphate receptor, S1P1, on T-cells controls thymic emigration. J Biol Chem 2004;279: 15396-15401.

5. Anderson KG, Mayer-Barber K, Sung H, et al. Intravascular staining for discrimination of vascular and tissue leukocytes. Nat Protoc 2014;9:209-222.

6. Anderson KG, Sung $\mathrm{H}$, Skon $\mathrm{CN}$, et al. Cutting edge: intravascular staining redefines lung $\mathrm{CD} 8 \mathrm{~T}$ cell responses. J Immunol 2012;189:2702-2706.

7. Ballesteros-Tato A, Leon B, Lund FE, and Randall TD. Temporal changes in dendritic cell subsets, cross-priming and costimulation via CD70 control CD8(+) T cell responses to influenza. Nat Immunol 2010;11:216-224.

8. Bankovich AJ, Shiow LR, and Cyster JG. CD69 suppresses sphingosine 1-phosophate receptor-1 (S1P1) function through interaction with membrane helix 4. J Biol Chem 2010;285:22328-22337.

9. Bautista BL, Devarajan P, McKinstry KK, et al. Shortlived antigen recognition but not viral infection at a defined checkpoint programs effector CD4 T cells to become protective memory. J Immunol 2016;197:3936-3949.

10. Belz GT, Smith CM, Kleinert L, et al. Distinct migrating and nonmigrating dendritic cell populations are involved in MHC class I-restricted antigen presentation after lung infection with virus. Proc Natl Acad Sci U S A 2004;101:8670-8675.

11. Braciale TJ, Sun J, and Kim TS. Regulating the adaptive immune response to respiratory virus infection. Nat Rev Immunol 2012;12:295-305.
12. Bromley SK, Thomas SY, and Luster AD. Chemokine receptor CCR7 guides $\mathrm{T}$ cell exit from peripheral tissues and entry into afferent lymphatics. Nat Immunol 2005;6: 895-901.

13. Cheuk S, Schlums H, Gallais Serezal I, et al. CD49a expression defines tissue-resident $\mathrm{CD}^{+} \mathrm{T}$ cells poised for cytotoxic function in human skin. Immunity 2017;46:287300.

14. Curtsinger JM, and Mescher MF. Inflammatory cytokines as a third signal for T cell activation. Curr Opin Immunol 2010;22:333-340.

15. Cyster JG, and Schwab SR. Sphingosine-1-phosphate and lymphocyte egress from lymphoid organs. Annu Rev Immunol 2012;30:69-94.

16. D'Souza WN, and Hedrick SM. Cutting edge: latecomer CD8 $\mathrm{T}$ cells are imprinted with a unique differentiation program. J Immunol 2006;177:777-781.

17. Daniels MA, and Teixeiro E. TCR signaling in $\mathrm{T}$ cell memory. Front Immunol 2015;6:617.

18. Day C, Patel R, Guillen C, and Wardlaw AJ. The chemokine CXCL16 is highly and constitutively expressed by human bronchial epithelial cells. Exp Lung Res 2009;35: 272-283.

19. Debes GF, Arnold CN, Young AJ, et al. Chemokine receptor CCR7 required for T lymphocyte exit from peripheral tissues. Nat Immunol 2005;6:889-894.

20. Desch AN, Randolph GJ, Murphy K, et al. $\mathrm{CD}_{103^{+}}$pulmonary dendritic cells preferentially acquire and present apoptotic cell-associated antigen. J Exp Med 2011;208: 1789-1797.

21. Duan S, and Thomas PG. Balancing immune protection and immune pathology by $\mathrm{CD} 8(+) \mathrm{T}$-cell responses to influenza infection. Front Immunol 2016;7:25.

22. Ebert S, Becker M, Lemmermann NA, et al. Mast cells expedite control of pulmonary murine cytomegalovirus infection by enhancing the recruitment of protective CD8 T cells to the lungs. PLoS Pathog 2014;10:e1004100.

23. Ely KH, Cauley LS, Roberts AD, et al. Nonspecific recruitment of memory $\mathrm{CD}^{+} \mathrm{T}$ cells to the lung airways during respiratory virus infections. J Immunol 2003;170: 1423-1429.

24. Ely KH, Cookenham T, Roberts AD, and Woodland DL. Memory $\mathrm{T}$ cell populations in the lung airways are maintained by continual recruitment. J Immunol 2006; 176:537-543.

25. Ely KH, Roberts AD, and Woodland DL. Cutting edge: effector memory $\mathrm{CD}^{+} \mathrm{T}$ cells in the lung airways retain the potential to mediate recall responses. J Immunol 2003; 171:3338-3342.

26. Erickson JJ, Gilchuk P, Hastings AK, et al. Viral acute lower respiratory infections impair $\mathrm{CD}^{+} \mathrm{T}$ cells through PD-1. J Clin Invest 2012;122:2967-2982.

27. Erickson JJ, Lu P, Wen S, et al. Acute viral respiratory infection rapidly induces a $\mathrm{CD} 8^{+} \mathrm{T}$ cell exhaustion-like phenotype. J Immunol 2015;195:4319-4330.

28. Erickson JJ, Rogers MC, Hastings AK, et al. Programmed death-1 impairs secondary effector lung CD8(+) T cells during respiratory virus reinfection. J Immunol 2014;193: 5108-5117.

29. Erickson JJ, Rogers MC, Tollefson SJ, et al. Multiple inhibitory pathways contribute to lung $\mathrm{CD}^{+} \mathrm{T}$ cell impairment and protect against immunopathology during acute viral respiratory infection. J Immunol 2016;197: 233-243. 
30. Fadel SA, Bromley SK, Medoff BD, and Luster AD. CXCR3-deficiency protects influenza-infected CCR5deficient mice from mortality. Eur J Immunol 2008;38: 3376-3387.

31. Fernandez IE, and Eickelberg O. The impact of TGF-beta on lung fibrosis: from targeting to biomarkers. Proc Am Thorac Soc 2012;9:111-116.

32. Frost EL, Kersh AE, Evavold BD, and Lukacher AE. Cutting edge: resident memory CD8 T cells express highaffinity TCRs. J Immunol 2015;195:3520-3524.

33. Galkina E, Thatte J, Dabak V, et al. Preferential migration of effector $\mathrm{CD}^{+} \mathrm{T}$ cells into the interstitium of the normal lung. J Clin Invest 2005;115:3473-3483.

34. Gebhardt T, Wakim LM, Eidsmo L, et al. Memory T cells in nonlymphoid tissue that provide enhanced local immunity during infection with herpes simplex virus. Nat Immunol 2009; 10:524-530.

35. GeurtsvanKessel $\mathrm{CH}$, and Lambrecht BN. Division of labor between dendritic cell subsets of the lung. Mucosal Immunol 2008;1:442-450.

36. GeurtsvanKessel CH, Willart MA, van Rijt LS, et al. Clearance of influenza virus from the lung depends on migratory langerin+CD11b- but not plasmacytoid dendritic cells. J Exp Med 2008;205:1621-1634.

37. Gilchuk P, Hill TM, Guy C, et al. A distinct lunginterstitium-resident memory CD8(+) T cell subset confers enhanced protection to lower respiratory tract infection. Cell Rep 2016;16:1800-1809.

38. Gough PJ, Garton KJ, Wille PT, et al. A disintegrin and metalloproteinase 10-mediated cleavage and shedding regulates the cell surface expression of CXC chemokine ligand 16. J Immunol 2004;172:3678-3685.

39. Grayson MH, Ramos MS, Rohlfing MM, et al. Controls for lung dendritic cell maturation and migration during respiratory viral infection. J Immunol 2007;179:14381448.

40. Gullberg D, Gehlsen KR, Turner DC, et al. Analysis of alpha 1 beta 1 , alpha 2 beta 1 and alpha 3 beta 1 integrins in cell-collagen interactions: identification of conformation dependent alpha 1 beta 1 binding sites in collagen type I. EMBO J 1992;11:3865-3873.

41. Heaton NS, Langlois RA, Sachs D, et al. Long-term survival of influenza virus infected club cells drives immunopathology. J Exp Med 2014;211:1707-1714.

42. Heer AK, Harris NL, Kopf M, and Marsland BJ. CD4 ${ }^{+}$ and $\mathrm{CD}^{+} \mathrm{T}$ cells exhibit differential requirements for CCR7-mediated antigen transport during influenza infection. J Immunol 2008;181:6984-6994.

43. Helft J, Manicassamy B, Guermonprez P, et al. Crosspresenting $\mathrm{CD}_{103^{+}}$dendritic cells are protected from influenza virus infection. J Clin Invest 2012;122:40374047.

44. Hikono H, Kohlmeier JE, Ely KH, et al. T-cell memory and recall responses to respiratory virus infections. Immunol Rev 2006;211:119-132.

45. Hikono H, Kohlmeier JE, Takamura S, et al. Activation phenotype, rather than central- or effector-memory phenotype, predicts the recall efficacy of memory CD8+ T cells. J Exp Med 2007;204:1625-1636.

46. Ho AW, Prabhu N, Betts RJ, et al. Lung $\mathrm{CD} 103^{+}$dendritic cells efficiently transport influenza virus to the lymph node and load viral antigen onto MHC class I for presentation to CD8 T cells. J Immunol 2011;187:60116021.
47. Hogan RJ, Cauley LS, Ely KH, et al. Long-term maintenance of virus-specific effector memory $\mathrm{CD} 8^{+} \mathrm{T}$ cells in the lung airways depends on proliferation. J Immunol 2002;169:4976-4981.

48. Hogan RJ, Usherwood EJ, Zhong W, et al. Activated antigen-specific $\mathrm{CD}^{+} \mathrm{T}$ cells persist in the lungs following recovery from respiratory virus infections. J Immunol 2001;166:1813-1822.

49. Hombrink P, Helbig C, Backer RA, et al. Programs for the persistence, vigilance and control of human $\mathrm{CD} 8^{+}$lungresident memory T cells. Nat Immunol 2016;17:1467-1478.

50. Hu JK, Kagari T, Clingan JM, and Matloubian M. Expression of chemokine receptor CXCR3 on T cells affects the balance between effector and memory CD8 T-cell generation. Proc Natl Acad Sci U S A 2011;108:E118E127.

51. Hu Y, Lee YT, Kaech SM, et al. Smad4 promotes differentiation of effector and circulating memory CD8 T cells but is dispensable for tissue-resident memory CD8 T cells. J Immunol 2015;194:2407-2414.

52. Iborra S, Martinez-Lopez M, Khouili SC, et al. Optimal generation of tissue-resident but not circulating memory $\mathrm{T}$ cells during viral infection requires crosspriming by DNGR-1+ dendritic cells. Immunity 2016;45:847-860.

53. Iijima $\mathrm{N}$, and Iwasaki A. Tissue instruction for migration and retention of TRM cells. Trends Immunol 2015;36: 556-564.

54. Jelley-Gibbs DM, Brown DM, Dibble JP, et al. Unexpected prolonged presentation of influenza antigens promotes CD4 $\mathrm{T}$ cell memory generation. J Exp Med 2005;202:697-706.

55. Jelley-Gibbs DM, Dibble JP, Brown DM, et al. Persistent depots of influenza antigen fail to induce a cytotoxic CD8 T cell response. J Immunol 2007;178:7563-7570.

56. Jennrich S, Lee MH, Lynn RC, et al. Tissue exit: a novel control point in the accumulation of antigen-specific CD8 $\mathrm{T}$ cells in the influenza a virus-infected lung. J Virol 2012;86:3436-3445.

57. Joshi NS, Cui W, Chandele A, et al. Inflammation directs memory precursor and short-lived effector CD8(+) T cell fates via the graded expression of T-bet transcription factor. Immunity 2007;27:281-295.

58. Kern A, Eble J, Golbik R, and Kuhn K. Interaction of type IV collagen with the isolated integrins alpha 1 beta 1 and alpha 2 beta 1. Eur J Biochem 1993;215:151-159.

59. Khan TN, Mooster JL, Kilgore AM, et al. Local antigen in nonlymphoid tissue promotes resident memory $\mathrm{CD} 8^{+} \mathrm{T}$ cell formation during viral infection. J Exp Med 2016; 213:951-966.

60. Kim TS, and Braciale TJ. Respiratory dendritic cell subsets differ in their capacity to support the induction of virus-specific cytotoxic $\mathrm{CD}^{+} \mathrm{T}$ cell responses. PLoS One 2009; 4:e4204.

61. Kim TS, Gorski SA, Hahn S, et al. Distinct dendritic cell subsets dictate the fate decision between effector and memory $\mathrm{CD} 8(+) \mathrm{T}$ cell differentiation by a CD24dependent mechanism. Immunity 2014;40:400-413.

62. Kim TS, Hufford MM, Sun J, et al. Antigen persistence and the control of local $\mathrm{T}$ cell memory by migrant respiratory dendritic cells after acute virus infection. J Exp Med 2010;207:1161-1172.

63. Klonowski KD, Williams KJ, Marzo AL, et al. Dynamics of blood-borne CD8 memory $\mathrm{T}$ cell migration in vivo. Immunity 2004;20:551-562. 
64. Kohlmeier JE, Miller SC, Smith J, et al. The chemokine receptor CCR5 plays a key role in the early memory $\mathrm{CD} 8^{+}$ $\mathrm{T}$ cell response to respiratory virus infections. Immunity 2008;29:101-113.

65. Kohlmeier JE, Miller SC, and Woodland DL. Cutting edge: antigen is not required for the activation and maintenance of virus-specific memory $\mathrm{CD}^{+} \mathrm{T}$ cells in the lung airways. J Immunol 2007; 178:4721-4725.

66. Kohlmeier JE, Reiley WW, Perona-Wright G, et al. Inflammatory chemokine receptors regulate CD8(+) T cell contraction and memory generation following infection. $\mathrm{J}$ Exp Med 2011;208:1621-1634.

67. Kohlmeier JE, and Woodland DL. Immunity to respiratory viruses. Annu Rev Immunol 2009;27:61-82.

68. Kumar PA, Hu Y, Yamamoto Y, et al. Distal airway stem cells yield alveoli in vitro and during lung regeneration following H1N1 influenza infection. Cell 2011;147: 525-538.

69. Kurachi M, Kurachi J, Suenaga F, et al. Chemokine receptor CXCR3 facilitates CD8(+) T cell differentiation into short-lived effector cells leading to memory degeneration. J Exp Med 2011;208:1605-1620.

70. Laidlaw BJ, Zhang N, Marshall HD, et al. $\mathrm{CD}^{+} \mathrm{T}$ cell help guides formation of CD103+ lung-resident memory $\mathrm{CD}^{+} \mathrm{T}$ cells during influenza viral infection. Immunity 2014;41:633-645.

71. Ledgerwood LG, Lal G, Zhang N, et al. The sphingosine 1-phosphate receptor 1 causes tissue retention by inhibiting the entry of peripheral tissue $\mathrm{T}$ lymphocytes into afferent lymphatics. Nat Immunol 2008;9:42-53.

72. Lee LN, Baban D, Ronan EO, et al. Chemokine gene expression in lung CD8 T cells correlates with protective immunity in mice immunized intra-nasally with Adenovirus85A. BMC Med Genomics 2010;3:46.

73. Lee LN, Ronan EO, de Lara C, et al. CXCR6 is a marker for protective antigen-specific cells in the lungs after intranasal immunization against Mycobacterium tuberculosis. Infect Immun 2011;79:3328-3337.

74. Lee YT, Suarez-Ramirez JE, Wu T, et al. Environmental and antigen receptor-derived signals support sustained surveillance of the lungs by pathogen-specific cytotoxic $\mathrm{T}$ lymphocytes. J Virol 2011;85:4085-4094.

75. Leon B, Ballesteros-Tato A, Randall TD, and Lund FE. Prolonged antigen presentation by immune complexbinding dendritic cells programs the proliferative capacity of memory CD8 T cells. J Exp Med 2014;211:1637-1655.

76. Lim K, Hyun YM, Lambert-Emo K, et al. Neutrophil trails guide influenza-specific CD8(+) $\mathrm{T}$ cells in the airways. Science 2015;349:aaa4352.

77. Lindell DM, Lane TE, and Lukacs NW. CXCL10/ CXCR3-mediated responses promote immunity to respiratory syncytial virus infection by augmenting dendritic cell and CD8(+) T cell efficacy. Eur J Immunol 2008;38: 2168-2179.

78. Mackay LK, Braun A, Macleod BL, et al. Cutting edge: CD69 interference with sphingosine-1-phosphate receptor function regulates peripheral $\mathrm{T}$ cell retention. J Immunol 2015;194:2059-2063.

79. Mackay LK, Minnich M, Kragten NA, et al. Hobit and Blimp1 instruct a universal transcriptional program of tissue residency in lymphocytes. Science 2016;352:459463.

80. Mackay LK, Rahimpour A, Ma JZ, et al. The developmental pathway for $\mathrm{CD} 103(+) \mathrm{CD} 8+$ tissue-resident memory $\mathrm{T}$ cells of skin. Nat Immunol 2013;14:12941301.

81. Mackay LK, Stock AT, Ma JZ, et al. Long-lived epithelial immunity by tissue-resident memory T (TRM) cells in the absence of persisting local antigen presentation. Proc Natl Acad Sci U S A 2012;109:7037-7042.

82. Mackay LK, Wynne-Jones E, Freestone D, et al. T-box transcription factors combine with the cytokines TGF-beta and IL-15 to control tissue-resident memory $\mathrm{T}$ cell fate. Immunity 2015;43:1101-1111.

83. Masopust D, and Picker LJ. Hidden memories: frontline memory $\mathrm{T}$ cells and early pathogen interception. J Immunol 2012;188:5811-5817.

84. Masopust D, Vezys V, Usherwood EJ, et al. Activated primary and memory CD8 T cells migrate to nonlymphoid tissues regardless of site of activation or tissue of origin. $\mathrm{J}$ Immunol 2004;172:4875-4882.

85. Matloubian M, David A, Engel S, et al. A transmembrane CXC chemokine is a ligand for HIV-coreceptor Bonzo. Nat Immunol 2000;1:298-304.

86. Matloubian M, Lo CG, Cinamon G, et al. Lymphocyte egress from thymus and peripheral lymphoid organs is dependent on S1P receptor 1. Nature 2004;427:355-360.

87. McGill J, and Legge KL. Cutting edge: contribution of lung-resident $\mathrm{T}$ cell proliferation to the overall magnitude of the antigen-specific CD8 $\mathrm{T}$ cell response in the lungs following murine influenza virus infection. J Immunol 2009;183:4177-4181.

88. McGill J, Van Rooijen N, and Legge KL. Protective influenza-specific CD8 $\mathrm{T}$ cell responses require interactions with dendritic cells in the lungs. J Exp Med 2008; 205:1635-1646.

89. McGill J, Van Rooijen N, and Legge KL. IL-15 transpresentation by pulmonary dendritic cells promotes effector CD8 T cell survival during influenza virus infection. J Exp Med 2010;207:521-534.

90. McKinstry KK, Strutt TM, Bautista B, et al. Effector CD4 $\mathrm{T}$-cell transition to memory requires late cognate interactions that induce autocrine IL-2. Nat Commun 2014; 5:5377.

91. McMaster SR, Wilson JJ, Wang H, and Kohlmeier JE. Airway-resident memory CD8 $\mathrm{T}$ cells provide antigenspecific protection against respiratory virus challenge through rapid IFN-gamma production. J Immunol 2015; 195:203-209.

92. McNally B, Ye F, Willette M, and Flano E. Local blockade of epithelial PDL-1 in the airways enhances $\mathrm{T}$ cell function and viral clearance during influenza virus infection. J Virol 2013;87:12916-12924.

93. Mikhak Z, Strassner JP, and Luster AD. Lung dendritic cells imprint $\mathrm{T}$ cell lung homing and promote lung immunity through the chemokine receptor CCR4. J Exp Med 2013;210:1855-1869.

94. Moltedo B, Li W, Yount JS, and Moran TM. Unique type I interferon responses determine the functional fate of migratory lung dendritic cells during influenza virus infection. PLoS Pathog 2011;7:e1002345.

95. Moyron-Quiroz JE, Rangel-Moreno J, Kusser K, et al. Role of inducible bronchus associated lymphoid tissue (iBALT) in respiratory immunity. Nat Med 2004;10: 927-934.

96. Mueller SN, and Mackay LK. Tissue-resident memory T cells: local specialists in immune defence. Nat Rev Immunol 2016;16:79-89. 
97. Muschaweckh A, Buchholz VR, Fellenzer A, et al. Antigen-dependent competition shapes the local repertoire of tissue-resident memory CD8+ T cells. J Exp Med 2016; 213:3075-3086.

98. Nawijn MC, Hackett TL, Postma DS, et al. E-cadherin: gatekeeper of airway mucosa and allergic sensitization. Trends Immunol 2011;32:248-255.

99. Newton AH, Cardani A, and Braciale TJ. The host immune response in respiratory virus infection: balancing virus clearance and immunopathology. Semin Immunopathol 2016;38:471-482.

100. Nobs SP, Schneider C, Heer AK, et al. PI3Kgamma is critical for dendritic cell-mediated $\mathrm{CD}^{+} \mathrm{T}$ cell priming and viral clearance during influenza virus infection. PLoS Pathog 2016;12:e1005508.

101. Palmer EM, Holbrook BC, Arimilli S, et al. IFNgammaproducing, virus-specific $\mathrm{CD} 8^{+}$effector cells acquire the ability to produce IL-10 as a result of entry into the infected lung environment. Virology 2010;404:225-230.

102. Pappu R, Schwab SR, Cornelissen I, et al. Promotion of lymphocyte egress into blood and lymph by distinct sources of sphingosine-1-phosphate. Science 2007;316: 295-298.

103. Ray SJ, Franki SN, Pierce RH, et al. The collagen binding alphalbeta1 integrin VLA-1 regulates CD8 T cell-mediated immune protection against heterologous influenza infection. Immunity 2004;20:167-179.

104. Richter M, Ray SJ, Chapman TJ, et al. Collagen distribution and expression of collagen-binding alphalbeta1 (VLA-1) and alpha2beta1 (VLA-2) integrins on CD4 and CD8 $\mathrm{T}$ cells during influenza infection. $\mathrm{J}$ Immunol 2007;178:4506-4516.

105. Richter MV, and Topham DJ. The alphalbeta1 integrin and TNF receptor II protect airway $\mathrm{CD}^{+}$effector T cells from apoptosis during influenza infection. J Immunol 2007; 179:5054-5063.

106. Sallusto F, Geginat J, and Lanzavecchia A. Central memory and effector memory $\mathrm{T}$ cell subsets: function, generation, and maintenance. Annu Rev Immunol 2004; 22:745-763.

107. Sallusto F, Lenig D, Forster R, et al. Two subsets of memory $\mathrm{T}$ lymphocytes with distinct homing potentials and effector functions. Nature 1999;401:708-712.

108. Sandoval F, Terme M, Nizard M, et al. Mucosal imprinting of vaccine-induced $\mathrm{CD}^{+} \mathrm{T}$ cells is crucial to inhibit the growth of mucosal tumors. Sci Transl Med 2013;5:172ra120.

109. Schultz-Cherry S, and Hinshaw VS. Influenza virus neuraminidase activates latent transforming growth factor beta. J Virol 1996;70:8624-8629.

110. Schwab SR, Pereira JP, Matloubian M, et al. Lymphocyte sequestration through S1P lyase inhibition and disruption of S1P gradients. Science 2005;309:1735-1739.

111. Seung E, Cho JL, Sparwasser T, et al. Inhibiting CXCR3dependent $\mathrm{CD}^{+} \mathrm{T}$ cell trafficking enhances tolerance induction in a mouse model of lung rejection. J Immunol 2011;186:6830-6838.

112. Shen CH, Ge Q, Talay O, et al. Loss of IL-7R and IL-15R expression is associated with disappearance of memory $\mathrm{T}$ cells in respiratory tract following influenza infection. J Immunol 2008;180:171-178.

113. Shin $H$, and Iwasaki A. A vaccine strategy that protects against genital herpes by establishing local memory $\mathrm{T}$ cells. Nature 2012;491:463-467.
114. Shiow LR, Rosen DB, Brdickova N, et al. CD69 acts downstream of interferon-alpha/beta to inhibit S1P1 and lymphocyte egress from lymphoid organs. Nature 2006; 440:540-544.

115. Skon CN, Lee JY, Anderson KG, et al. Transcriptional downregulation of S1pr1 is required for the establishment of resident memory $\mathrm{CD}^{+} \mathrm{T}$ cells. Nat Immunol 2013; 14:1285-1293.

116. Slütter B, Pewe LL, Kaech SM, and Harty JT. Lung airway-surveilling CXCR3(hi) memory CD8(+) T cells are critical for protection against influenza A virus. Immunity 2013;39:939-948.

117. Slütter B, Van Braeckel-Budimir N, Abboud G, et al. Dynamics of influenza-induced lung-resident memory $\mathrm{T}$ cells underlie waning heterosubtypic immunity. Sci Immunol 2017;2:eaag2031.

118. Sowell RT, Rogozinska M, Nelson CE, et al. Cutting edge: generation of effector cells that localize to mucosal tissues and form resident memory CD8 T cells is controlled by mTOR. J Immunol 2014;193:20672071.

119. Steinert EM, Schenkel JM, Fraser KA, et al. Quantifying memory CD8 $\mathrm{T}$ cells reveals regionalization of immunosurveillance. Cell 2015;161:737-749.

120. Sun J, Dodd H, Moser EK, et al. $\mathrm{CD}^{+} \mathrm{T}$ cell help and innate-derived IL-27 induce Blimp-1-dependent IL-10 production by antiviral CTLs. Nat Immunol 2011;12:327334.

121. Sun J, Madan R, Karp CL, and Braciale TJ. Effector T cells control lung inflammation during acute influenza virus infection by producing IL-10. Nat Med 2009;15: 277-284.

122. Takamura S, Roberts AD, Jelley-Gibbs DM, et al. The route of priming influences the ability of respiratory virusspecific memory $\mathrm{CD}^{+} \mathrm{T}$ cells to be activated by residual antigen. J Exp Med 2010;207:1153-1160.

123. Takamura S, Yagi H, Hakata Y, et al. Specific niches for lung-resident memory $\mathrm{CD}^{+} \mathrm{T}$ cells at the site of tissue regeneration enable CD69-independent maintenance. J Exp Med 2016;213:3057-3073.

124. Teijaro JR, Walsh KB, Cahalan S, et al. Endothelial cells are central orchestrators of cytokine amplification during influenza virus infection. Cell 2011;146:980-991.

125. Thatte J, Dabak V, Williams MB, et al. LFA-1 is required for retention of effector CD8 $\mathrm{T}$ cells in mouse lungs. Blood 2003;101:4916-4922.

126. Turner DL, Bickham KL, Thome JJ, et al. Lung niches for the generation and maintenance of tissue-resident memory T cells. Mucosal Immunol 2013;3:501-510.

127. van der Voort R, Verweij V, de Witte TM, et al. An alternatively spliced CXCL16 isoform expressed by dendritic cells is a secreted chemoattractant for CXCR6+ cells. J Leukoc Biol 2010;87:1029-1039.

128. Vandenberg P, Kern A, Ries A, et al. Characterization of a type IV collagen major cell binding site with affinity to the alpha 1 beta 1 and the alpha 2 beta 1 integrins. J Cell Biol 1991;113:1475-1483.

129. Vaughan AE, Brumwell AN, Xi Y, et al. Lineage-negative progenitors mobilize to regenerate lung epithelium after major injury. Nature 2015;517:621-625.

130. Verbist KC, Cole CJ, Field MB, and Klonowski KD. A role for IL-15 in the migration of effector CD8 T cells to the lung airways following influenza infection. J Immunol 2011;186:174-182. 
131. Verbist KC, Field MB, and Klonowski KD. Cutting edge: IL-15-independent maintenance of mucosally generated memory CD8 T cells. J Immunol 2011;186:6667-6671.

132. Wakim LM, Gupta N, Mintern JD, and Villadangos JA. Enhanced survival of lung tissue-resident memory CD8(+) $\mathrm{T}$ cells during infection with influenza virus due to selective expression of IFITM3. Nat Immunol 2013;14: 238-245.

133. Wakim LM, Smith J, Caminschi I, et al. Antibodytargeted vaccination to lung dendritic cells generates tissue-resident memory CD8 $\mathrm{T}$ cells that are highly protective against influenza virus infection. Mucosal Immunol 2015;8:1060-1071.

134. Wareing MD, Lyon AB, Lu B, et al. Chemokine expression during the development and resolution of a pulmonary leukocyte response to influenza A virus infection in mice. J Leukoc Biol 2004;76:886-895.

135. Wu T, Hu Y, Lee YT, et al. Lung-resident memory CD8 T cells (TRM) are indispensable for optimal cross-protection against pulmonary virus infection. J Leukoc Biol 2014; 95:215-224.

136. Yadava K, Sichelstiel A, Luescher IF, et al. TSLP promotes influenza-specific CD8+ T-cell responses by augmenting local inflammatory dendritic cell function. Mucosal Immunol 2013;6:83-92.
137. Zaid A, Mackay LK, Rahimpour A, et al. Persistence of skin-resident memory $\mathrm{T}$ cells within an epidermal niche. Proc Natl Acad Sci U S A 2014;111:5307-5312.

138. Zammit DJ, Turner DL, Klonowski KD, et al. Residual antigen presentation after influenza virus infection affects CD8 T cell activation and migration. Immunity 2006;24: 439-449.

139. Zens KD, Chen JK, and Farber DL. Vaccine-generated lung tissue-resident memory $\mathrm{T}$ cells provide heterosubtypic protection to influenza infection. JCI Insight 2016;1:e85832.

140. Zuo W, Zhang T, Wu DZ, et al. p63(+)Krt5(+) distal airway stem cells are essential for lung regeneration. Nature 2015;517:616-620.

Address correspondence to:

Dr. Shiki Takamura

Department of Immunology

Kindai University Faculty of Medicine 377-2 Ohno-Higashi

Osaka-Sayama

Osaka 589-8511

Japan

E-mail: takamura@med.kindai.ac.jp 